\title{
NEW TECHNOLOGIES OF HALOAEROSOLTHERAPY AT ASTHMATIC PATIENTS
}

\author{
Ivan S.Lemko, Olha I.Lemko \\ Government Institution "The Scientific-practical Medical Centre "Rehabilitation” Health Ministry of Ukraine”, \\ Uzhgorod, Ukraine
}

Key words: speleotherapy, haloaerosoltherapy, different regimes of treatment

\section{Introduction:}

Speleotherapy - is the method of treatment in conditions of mines and karst caves microclimate. At 40-50-th this method have begun to develop in Germany, Austria and Italy. Later at the 60-th years speleotherapy was put in to practice in East Europe (Poland, Hungary, Slovakia, Romania). The high efficiency of this method of treatment at bronchial asthma (BA) patients is proved.

However, there are technical reasons and medical contraindications, which do not give opportunities to some patients to be put down in underground department. Therefore, the apparatus, which enables to create an highdispersed aerosol of rock salt (haloaerosol) on the surface of the ground was worked out. The method of haloaerosoltherapy with the use of highdispersed aerosol of rock salt is successfully applied in Ukraine about 20 years.

More than 10 years one regimen of treatment was applied in all patients. The course of treatment lasted 24 days and included 21-22 seanses of haloaerosoltherapy during 60minutes everyone. However, new economic conditions dictate necessity of improvement and reconsideration of some well-known methods of treatment on the basis of new data about bronchoobstruction mechanisms and new technical decisions.

The way to increase the effectiveness of patients treatment in conditions of rock salt aerosol medium is the development of technologies, which allow to receive an aerosol of the given concentration and dispersion with the purpose of needed influence on various levels of the respiratory tract.
The laser-optical system allowing to define a dispersion and concentration of rock salt aerosol was worked out. It has enabled to dosage an aerosol and to reduce the medical course.

Aim: The main aim of our work was the approbation of different haloaerosoltherapy regimens in dependence of current diseases peculiarities and functional condition of the broncho-pulmonary system. The effectiveness of usual 24-day's treatment course, which included a daily 60-th minutes seanses of haloaeorosoltherapy (control group) with the reduced courses (research group) was compared.

\section{Materials and methods:}

There are 116 patients with mild and moderate persistent bronchial asthma (BA) were investigated. The patients were from 18 till 56 years old. The average period of illness was about 7,4 $\pm 2,5$ years. All patients passed usual clinical, laboratory and functional examinations. The functional investigations of bronchopulmonary system included the definition of bronchoobstruction level and its primary mechanism on the basis of pharmacological tests. All patients were divided into 3 groups depending on ventilation's disturbances:

- patients with normal pulmonary functional tests (PFT);

- asthma patients with moderate disturbances of lungs ventilation;

- asthma patients with severe disturbances of PFT.

All patients were treated according to 3 medical complexes (MC) (table 1): 
Table 1 Medical complexes

\begin{tabular}{|c|c|c|c|c|}
\hline $\begin{array}{c}\text { Medical } \\
\text { complexes }\end{array}$ & $\begin{array}{c}\text { Duration of } \\
\text { treatment course }\end{array}$ & $\begin{array}{c}\text { Quantity of haloarosoltherapy } \\
\text { seances }\end{array}$ & $\begin{array}{c}\text { Duration of seance } \\
\text { of aerosol }\end{array}$ \\
\hline MC-1 & $24-25$ days & $21-22$ & 60 minutes & Standard \\
\hline MC-2 & 18 days & $15-16$ & 60 minutes & Standard \\
\hline MC-3 & 18 days & $15-16$ & $\begin{array}{c}\text { two consecutive seances by } \\
30 \text { minutes }\end{array}$ & Increased \\
\hline
\end{tabular}

MC-1 lasted 24 days and included 21-22 seances of the haloaerosoltherapy in special rooms by a standard method during 60 minutes everyone (control group). MC-2 lasted 18 days and included 15-16 seances of haloaerosoltherapy and the duration of one seance was 60 minutes. MC-3 lasted 18 days and consisted of 15-16 seanses of haloaerosoltherapy for a course, but each seance included consecutive stay in 2 special rooms with the increased concentration of rock salt aerosol for 30 minutes in everyone.

\section{Results:}

Analyzing the clinical data of asthma patients with normal PFT under the influence of different haloaeorosoltherapy regimens it was marked, that all three medical complexes had positive effect on the disease current, however influence of MC-2 and MC-3 were more expressed and significant. The prescription of MC-2 and MC-3 resulted in disappearance of the suffocation attacks in all patients. The single whistling rales were detecting only at $11,1 \%$ and $8,3 \%$ of patients after MC-2 and MC-3 accordingly. These data were confirmed by changes in reception of bronchodilatators supportive doze. The patients, who passed the haloaerosoltherapy according to MC-2 and MC3 discontinued the reception of bronchodilatators. The parameters of PFT varied in normal level and their changes were not significant.

The integrated estimation of treatment efficiency of asthma patients with normal PFT included clinical, functional and laboratory criteria (Fig.1).

Fig.1. Effectivness of different regimens of haloaerosoltherapy at asthma patients with normal PFT

The improvement of disease current was established at $56 \%$ of patients after MC- 1 , at $75 \%$ of cases after MC- 2 and at $86 \%$ of asthma patients after MC-3. Thus we can recommend the reduced regimens of haloaerosoltherapy to patients, who enrolling for treatment without disturbances of ventilation.

The other dynamics of clinical data under the influence of different regimens of haloaerosoltherapy was observed in patients with the moderate disturbances of ventilation. All medical complexes made positive influence in asthma patients (table 2). But at the end of treatment $38 \%$ of patients, who accepted MC-1 still had suffocation attacks, while after MC-2

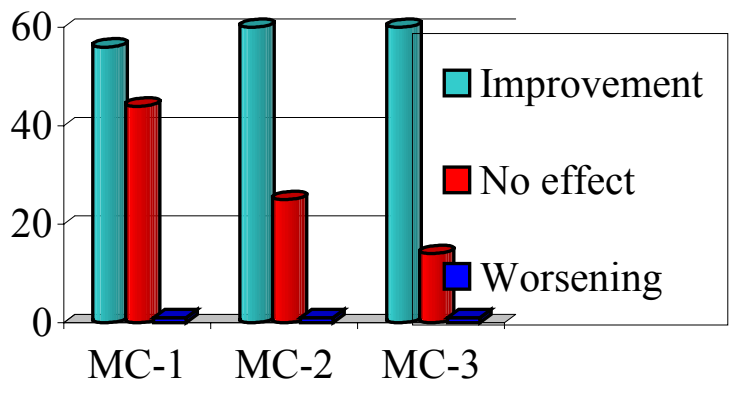

and MC-3 this parameter was much lower (23\% and $14 \%$ accordingly). The dry rales, single mainly, were detected in $48 \%$ of patients after $\mathrm{MC}-1$, in $38 \%$ of ones after MC-2, and in 34\% of asthma patients after MC-3. 
Table 2 Clinical data at the asthma patients with moderate disturbances of ventilation under influence of haloaerosoltherapy

\begin{tabular}{|c|c|c|c|c|c|c|}
\hline \multirow{2}{*}{$\begin{array}{c}\text { Clinical } \\
\text { data }\end{array}$} & \multicolumn{2}{|c|}{ MC-1 } & \multicolumn{2}{|c|}{ MC-2 } & \multicolumn{2}{|c|}{ MC-3 } \\
\hline & $\begin{array}{c}\text { before } \\
\text { treat-ment, } \\
\%\end{array}$ & $\begin{array}{c}\text { after treat- } \\
\text { ment, } \%\end{array}$ & $\begin{array}{c}\text { before } \\
\text { treat-ment, } \\
\%\end{array}$ & $\begin{array}{c}\text { after treat- } \\
\text { ment, } \%\end{array}$ & $\begin{array}{c}\text { before } \\
\text { treat-ment, } \\
\%\end{array}$ & $\begin{array}{c}\text { after treat- } \\
\text { ment, } \%\end{array}$ \\
\hline Attack of BA & & & & & & \\
\hline -mild & 67 & 33 & 72 & 23 & 76 & 14 \\
\hline -moderate & 15 & 5 & 19 & - & 14 & - \\
\hline Dry rales: & & & & & & \\
\hline -single & 43 & 38 & 38 & 38 & 33 & 29 \\
\hline -diffuse & 19 & 10 & 38 & - & 62 & 5 \\
\hline $\begin{array}{l}\beta_{2} \text {-agonist } \\
\text { taking: }\end{array}$ & & & & & & \\
\hline -sporadic & 14 & 10 & 10 & 10 & 10 & 10 \\
\hline -daily & 57 & 33 & 62 & 14 & 57 & 14 \\
\hline
\end{tabular}

These data were confirmed by changes of supporting bronchodilatator therapy and by the dynamics of parameters of PFT. The most significant increase of parameters (at 10-15\%) at all levels of a bronchial tree, was designated under the influence of MC-2 (Fig.2).

These results have founded the reflection in the integrated estimation of effectiveness of different medical complexes There were $52 \%$ of the patients who were discharged with improvement after MC-1, 81\% of ones - after MC- 2 and $76 \%$ of the patients - after MC-3. It is necessary to note, that the increased concentration of rock salt aerosole, which was used at MC-3 provoked the aggravation of process in some patients $(5 \%)$. Therefore the prescription of $\mathrm{MC}-2$ is optimum for the patients with moderate distrubances of ventilation.

Fig.2. PFT data at asthma patients with moderate disturbances of ventilation under the influence MC-2

The reduction of disease clinical data under influence of haloaerosoltherapy passed less intensively at the patients, who were enrolling to hospital with severe infringements of PFT (table 3). The most expressive reduction of frequency and intensity of asthma attacks were observed at prescription of MC-3, which is proved to be true by objective examination data and by volume of necessary supporting bronchodilatator therapy.

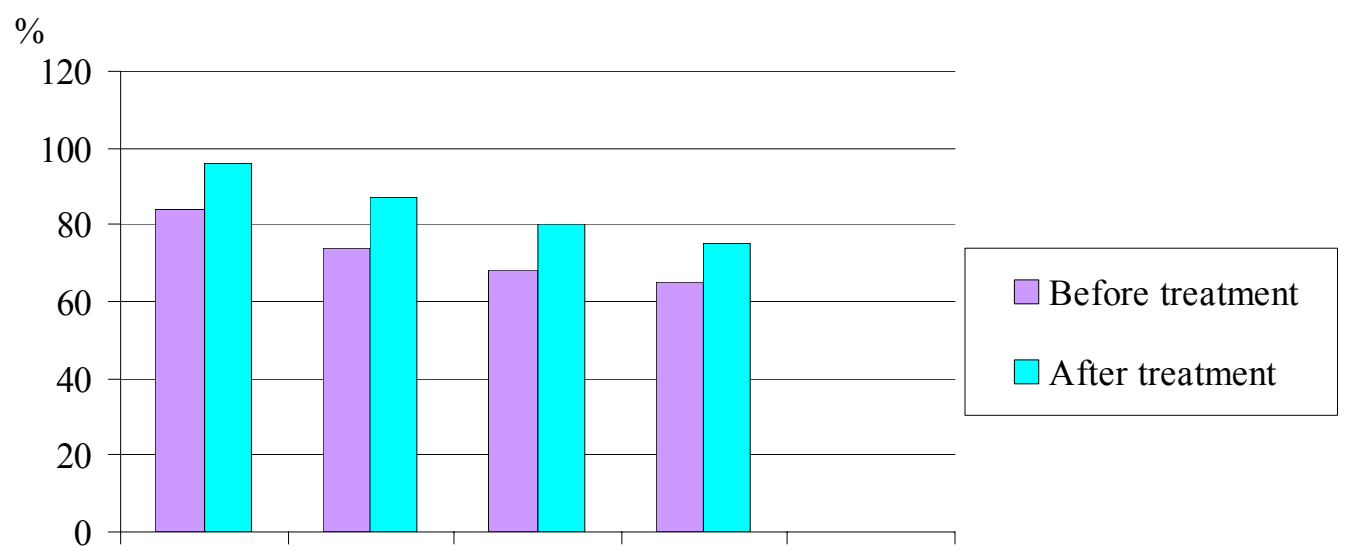

FEV1 MEF 25 MEF 50 MEF 75 
Table 3 Clinical data at asthma patients with severe disturbances of ventilation under influence of haloaerosoltherapy

\begin{tabular}{|c|c|c|c|c|c|c|}
\hline \multirow{2}{*}{$\begin{array}{c}\text { Clinical } \\
\text { data }\end{array}$} & \multicolumn{2}{|c|}{ MC-1 } & \multicolumn{2}{|c|}{ MC-2 } & \multicolumn{2}{|c|}{ MC-3 } \\
\hline & $\begin{array}{c}\text { before } \\
\text { treat-ment, \% }\end{array}$ & $\begin{array}{l}\text { after treat- } \\
\text { ment, } \%\end{array}$ & $\begin{array}{c}\text { before } \\
\text { treat-ment, } \%\end{array}$ & $\begin{array}{c}\text { after treat- } \\
\text { ment, } \%\end{array}$ & $\begin{array}{c}\text { before } \\
\text { treat-ment, \% }\end{array}$ & $\begin{array}{c}\text { after treat- } \\
\text { ment, } \%\end{array}$ \\
\hline \multicolumn{7}{|l|}{ Attack of BA: } \\
\hline -mild & 70 & 70 & 39 & 23 & 56 & 22 \\
\hline -moderate & 30 & - & 62 & 38 & 44 & 11 \\
\hline \multicolumn{7}{|l|}{ Dry rales: } \\
\hline -single & 10 & 60 & 23 & 39 & 28 & 56 \\
\hline -diffuse & 90 & 20 & 77 & 39 & 72 & 17 \\
\hline \multicolumn{7}{|c|}{$\beta_{2}$-agonist taking: } \\
\hline -sporadic & - & 30 & 23 & 23 & 6 & 34 \\
\hline -daily & 80 & 30 & 77 & 56 & 94 & 22 \\
\hline
\end{tabular}

So, at the end of treatment the suffocation attacks were kept at $70 \%$ of the patients after MC-1, at $61 \%$ of ones after MC-2 and only at $33 \%$ of the patients after assignment of MC-3. Significant increase of all parameters of PFT was also established at the patients, which passed haloaerosoltherapy according to MC-3 (Fig.3.).

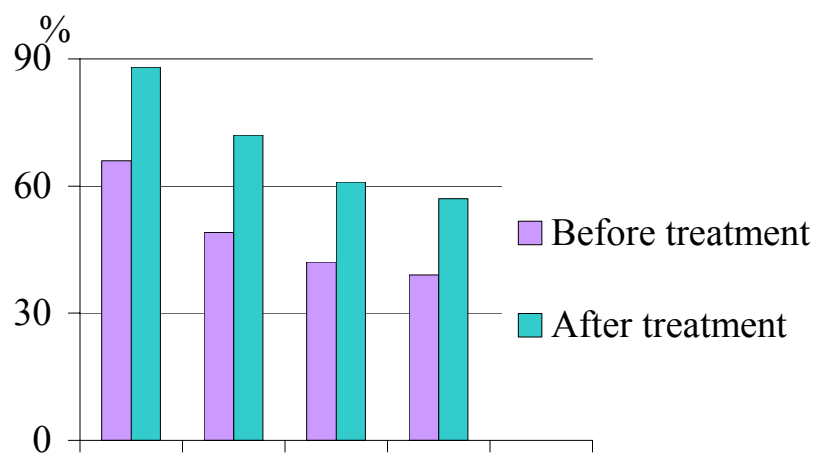

Fig.3. PFT data at asthma patients with severe disturbances of ventilation under the influence MC-3

The received results are coincided with an integrated estimation of the treatment effectiveness. There were $70 \%$ of the patients who were discharged from hospital with improvement after $\mathrm{MC}-1,38 \%$ of ones, who received $\mathrm{MC}-2$ and $88 \%$ of the patients, who passed haloaerosoltherapy according to MC-3.

\section{Conclusions:}

Accordingly, the new principled approaches in elaboration of technologies of recovering treatment and staged rehabilitation of the patients taking into account the peculiarities of broncho-pulmonary system functional condition and bronchial reactivity extend the opportunities of haloaerosoltherapy, increase its effectiveness, allow to reduce material expenditures to the patients treatment, and can be recommended for application in medical institutions.

\section{Bibliography:}

1. М.Д. Торохтин, Я.В. Чонка, И.С. Лемко и др. Спелеотерапия заболеваний органов дыхания в условиях микроклимата соляных шахт. Ужгород: Закарпаття, 1998. - 288c.

2. Л.А. Верихова. Спелеотерапия в России. Пермь, 2000. - 231c.

3. Tibor Horvath. Speleotherapy in Europe: Past, present and future. 10 Internationales Symposium für Speläotherapie. Bad Bleiberg, 1992. - P.15-17.

4. Iu (Ghe.) Simionca, L. Enache, M. Hoteteu et al. Perspectives for speleotherapy in Romanian saline mines and caves. Speleotherapy in the salt mine in Solotvino. Solotvino, 2006. - P.9-11.

5. I.S. Lemko, Y.V. Chonka, J.P. Charkan at al. Study of the aerosol systems by a digital vidiosurvey. Speleotherapy in the salt mine in Solotvino. Solotvino, 2006. - P.17-18. 